\title{
Enrichment Characteristics, Occurrence and Origin of Valuable Trace Elements in Lignite from Linchang Coal Mine, Guangxi, China
}

\author{
De'e Qi, Shihao Wu, Shenyong Li*, Gui Zhao, Jingkai Xing, Shuai Kang, Qian Wang, Wenyue Gao \\ Key Laboratory for Resource Exploration Research of Hebei Province, Hebei University of Engineering, Handan, China \\ Email: qdesxfy@163.com,wushihao8@163.com, *shenyong360@hebeu.edu.cn,18584096803@163.com, \\ xjk1413110920@163.com, kang0927111@163.com,wq312737@163.com,linda.gao2018@outlook.com
}

How to cite this paper: Qi, D. E., Wu, S. H., Li, S. Y., Zhao, G., Xing, J. K., Kang, S., Wang, Q., \& Gao, W. Y. (2021). Enrichment Characteristics, Occurrence and Origin of Valuable Trace Elements in Lignite from Linchang Coal Mine, Guangxi, China. Journal of Geoscience and Environment Protection, 9, 133-150.

https://doi.org/10.4236/gep.2021.912009

Received: November 12, 2021

Accepted: December 26, 2021

Published: December 29, 2021

Copyright (c) 2021 by author(s) and Scientific Research Publishing Inc. This work is licensed under the Creative Commons Attribution-NonCommercial International License (CC BY-NC 4.0). http://creativecommons.org/licenses/by-nc/4.0/ (c) (i) \$ Open Access

\begin{abstract}
To evaluate the comprehensive exploitation and utilization values of coal resources in Baise basin of Guangxi, the Paleogene coal of Linchang coal mine were sampled and studied. The enrichment characteristics, occurrence modes, and geochemical origin of valuable trace elements in coal were studied by using X-ray diffraction (XRD), scanning electron microscope-energy dispersive X-ray spectrometer (SEM-EDS), polarizing microscope, X-ray fluorescence spectrometry (XRF), inductively coupled plasma mass spectrometry (ICP-MS) and atomic fluorescence spectrometry (AFS). The results reveal that Linchang coal is ultra-low calorific value lignite with high ash, medium sulfur, medium-high moisture and medium volatilization. The minerals are mainly composed of illite, kaolinite, quartz, pyrite, siderite, bassanite, anhydrite and magnesium-containing calcite. Compared with average values for world low-rank coals, the contents of valuable trace elements in Linchang coal are higher on the whole, which is characterized by the high enrichment of $\mathrm{U}$, the enrichment of elements $\mathrm{Li}, \mathrm{V}$ and $\mathrm{Ag}$, and the slight enrichment of elements Be, Ga and Se. Lithium, V, Ga and Ag mainly occur in clay minerals including illite and kaolinite, and part of $\mathrm{V}$ is related to organic matter. The carriers of Be in coal are clay minerals and organic matter. Selenium is mainly combined with organic matter and a small amount exists in pyrite. Uranium is primarily organically bound in coal. The enrichment of valuable trace elements in Linchang coal is influenced by the sedimentary source, coalforming environment, underground circulating water and geological structure. The sedimentary environment of the coal seam is an acid-reduced terrestrial peat swamp, and the source is Triassic sedimentary rocks weathered from feldspathic volcanic rocks around Baise basin.
\end{abstract}




\section{Keywords}

Lignite, Valuable Trace Elements, Enrichment Characteristics, Occurrence Modes, Geochemical Origin

\section{Introduction}

With the development of coal geochemistry research, the concept of coal has been evolved from the original fossil fuel to "fossil fuel and ore deposit", which can be divided into an energy resource, metal minerals and non-metal mineral resource of coal-bearing series (Sun et al., 2014). Coal-bearing metal deposits refer to metal elements that can be mined and utilized from coal seams, gangues or surrounding rock of coal seams under current technical and economic conditions (Ning et al., 2017a; Ning et al., 2017b). In recent years, large scale coalbearing rare metal minerals, such as coal seam-hosted germanium, uranium, and gallium deposits, have been found in Inner Mongolia, Shanxi and YunnanGuizhou regions in China (Seredin \& Dai, 2012; Qin et al., 2015a; Chen et al., 2017; Dai et al., 2018; Chen et al., 2018), which has attracted extensive attention to the investigation of valuable trace elements enriched in coal. With the increasing demand for valuable trace elements in emerging industries such as aerospace, defense and military industry in China, it is of great significance to extract and utilize associated elements from coal. At present, valuable trace elements including uranium, germanium, and gallium have been successfully extracted on an industrial scale from coal or coal ash (Dai et al., 2018). In addition, other valuable trace elements in coal, such as lithium, beryllium, selenium, vanadium and silver, are also the main objects to be found and utilized in coal seam. The Baise basin is one of the most important coal industrial bases in Guangxi province. The coal resources in this area are characterized by high ash content, low heat, and high sulfur content. From the perspective of coal alone, it has not been widely exploited for a long time due to its low industrial mining value. However, if a certain scale of coal-associated metal resources can be found from coal measures and utilized comprehensively, the mining value of coal resources in the Baise basin can be greatly enhanced. Many scholars reported a series of organic geochemical characteristics of lignite in Zhoujing mine, Baise basin (Wang \& Simoneit, 1990; Zhao et al., 1990). So far, only Yan et al. (2019) have studied the trace elements in Zhoujing coal in the Baise basin, but few studies are focusing on valuable elements in Baise coal. As a result, we collected Paleogene coal samples from Linchang coal mine located in the Baise basin and analyzed their geochemical experimental data to determine their composition characteristics and occurrence modes of valuable elements. Based on previous researches, as well as the geological structure, sedimentary background and the enrichment characteristics of valuable trace elements in the mining area, the geochemical origin and mechanism of these valuable elements are then dis- 
cussed. The study will be beneficial to the coal mining and comprehensive utilization in the Baise basin in China.

\section{Geological Background}

The Baise Coal Field is situated in Baise city, Guangxi province, in the middle of the Youjiang fold belt of the South China fold system. It is a half graben basin with steep north and gentle asymmetrical south. The Baise Basin develops faults, which are dominated by NW-trending normal faults. There are also NNE and NNW-trending faults cutting the NW-trending structure. The Linchang coal mine is located in Baiyu town, Tianyang county, Baise city, which has about 6.85 $\mathrm{km}^{2}$, and complex geological structure and relatively developed faults. Four faults are found in total (Figure 1). The strata of the mining area are divided into Nadu member (E2nn), Tiandong member (E2nt), Lower Baigang member (E2nb) of Paleogene Nadu Formation, Upper Baigang member (E3gb) of Gongkang Formation and Quaternary (Q). The coal-bearing stratum is the Lower Baigang member of the Nadu Formation, with a thickness of $200-320 \mathrm{~m}$ (260 $\mathrm{m}$ on average), and the coal-accumulating environment of which is in the order of deltaic plain swamp, estuarine delta bay swamp and river floodplain, and
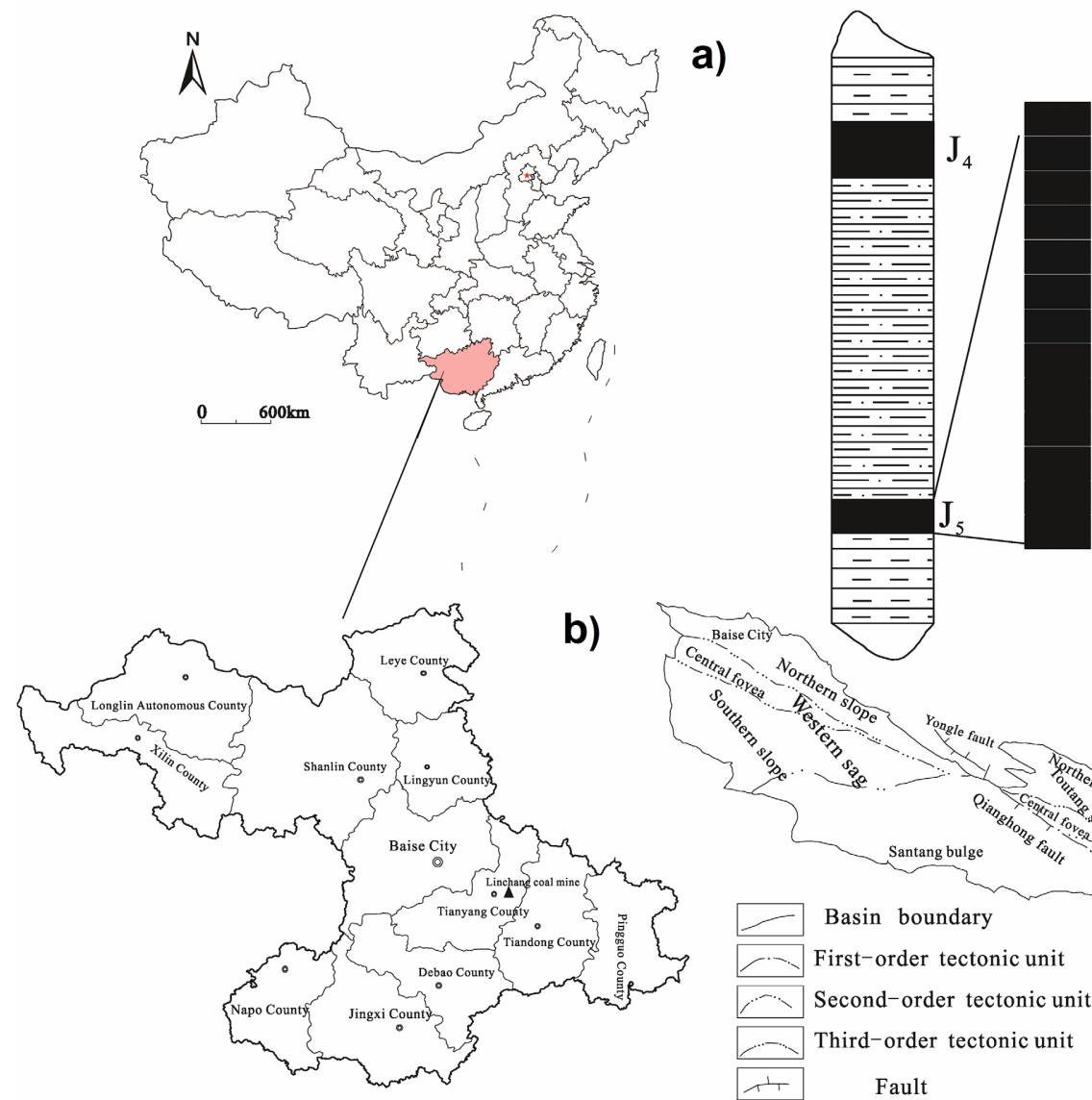

C)

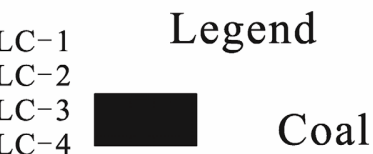

$\mathrm{LC}-4$

$\mathrm{LC}-5$

$\begin{array}{ll}\mathrm{LC}-6 & ---- \\ \mathrm{LC}-7 & ---1\end{array}$

Sandy LC-8 mudstone

$\mathrm{LC}-9$

LC-10 Mudstone LC -11 LC -12 $\mathrm{LC}-13$

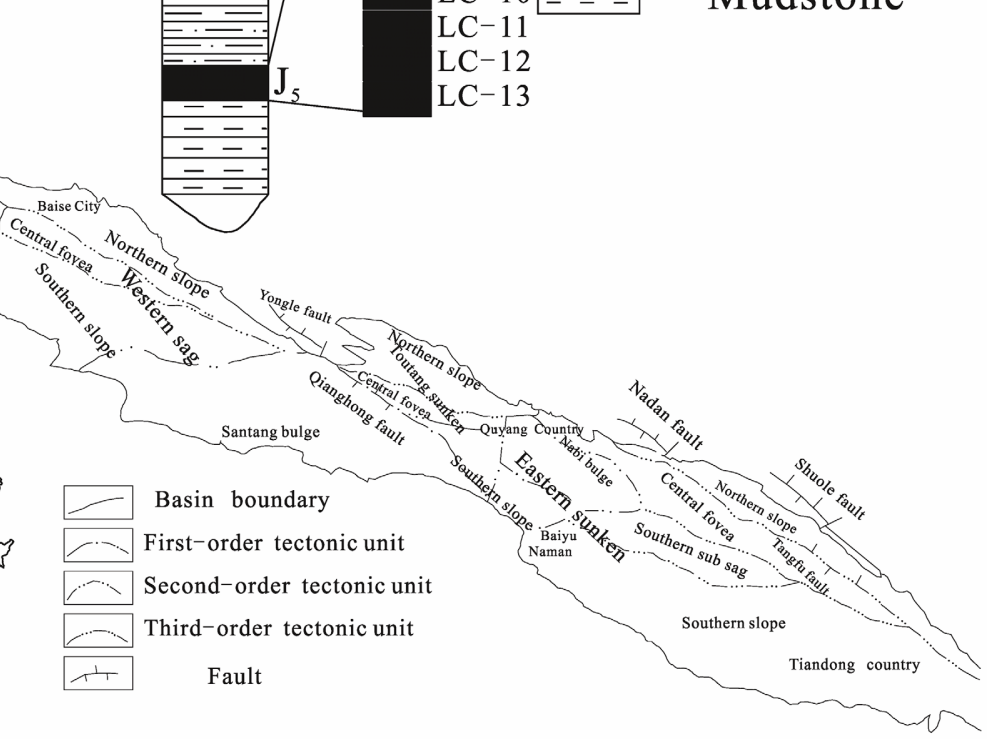

Figure 1. (a) Location of the Linchang coal mine in China; (b) Structural map of Baise Basin (Adapted from (Liao et al., 2005)); (c) Sedimentary sequences in the Linchang mine and the section of the $\mathrm{J}_{5}$ coal seam. 
shallow lake swamp. Its strata are mainly composed of mudstone, sandy mudstone, siltstone, argillaceous sandstone and more than ten layers of coal seams, but only two seams of $\mathrm{J}_{4}$ and $\mathrm{J}_{5}$ can be mined. The main coal seam of $\mathrm{J}_{5}$ is relatively stable and mostly mineable, with a thickness of $0.8-1.35 \mathrm{~m}(1.02 \mathrm{~m}$ on average). The structure of the $\mathrm{J}_{5}$ coal seam is simple and relatively stable. The roof is made of chalky sandstone, sandy mudstone and mudstone, with 0 - 5 layers of gangue, and the floor is mudstone, sandy mudstone and argillaceous sandstone. The $\mathrm{J}_{4}$ coal seam is unstable, and only its east is minable.

\section{Sample Collection and Methods}

In this study, the $\mathrm{J}_{5}$ coal seam of Linchang coal mine in Baise Coalfield from Guangxi was selected as the research object. According to the Chinese standard GB/T 482-2008, a total of 13 bench coal samples were collected and numbered from top to bottom as LC-1 - LC-13 (Figure 1). No obvious parting layer was found during the sampling process. All collected samples are immediately stored in sealed bags to avoid contamination and oxidation.

After the samples are naturally air-dried, and then crushed and ground to $<200$, mesh for proximate analysis such as moisture, ash, volatile, calorific value and total sulfur. According to GB/T 6984-1998 "Determination method of vitrinite reflectance", the huminite reflectance of coal samples is measured, which is defined as the proportion of incident light reflected from polished vitrinite surface, and the macerals are observed and counted. The minerals in low-temperature ashing $\left(\mathrm{LTA}, 120^{\circ} \mathrm{C}\right)$ coal are analyzed qualitatively by X-ray diffraction (XRD, Quorum K1050X-D/Rigaku MAX2200PC), and quantitative analysis is performed with Siroquant ${ }^{\mathrm{TM}}$ software. The mineral species and morphology in coal are identified by polarizing microscope (Leica DM2500P) and scanning electron microscope-energy dispersive X-ray spectrometer (SEM-EDS, Hitachi SU8220). X-ray fluorescence spectrometry (XRF) is used to analyze the major element oxides in the ash samples, and inductively coupled plasma mass spectrometry (ICP-MS) is used to determine the content of valuable trace elements in coal, in which selenium ( $\mathrm{Se}$ ) is determined by atomic fluorescence spectrometry (AFS). All analyses were performed in the Key Laboratory of Resource Exploration Research of Hebei Province.

\section{Results and discussion}

\subsection{Coal Quality and Maceral}

The results of proximate analysis, total sulfur content and calorific value of Linchang coal are given in Table 1 . The average moisture content of the coal sample is $15.44 \%$, which belongs to medium-high moisture coal. Linchang coals exhibit a high ash yield ( $46.15 \%$ on average), medium volatile content $(21.69 \%$ on average) and extra-low gross calorific values (10.34 MJ/kg on average). Coal samples have an average of $1.39 \%$ total sulfur, corresponding to medium sulfur coal.

As presented in Table 1, the huminite reflectance $\left(R_{\mathrm{o}}\right)$ value is $0.40 \%$, indicating 
Table 1. Proximate analysis and huminite reflectance Ro in Linchang coal (\%).

\begin{tabular}{|c|c|c|c|c|c|c|c|c|c|c|c|}
\hline \multirow{2}{*}{ Samples } & \multicolumn{6}{|c|}{ Coal Quality } & \multicolumn{4}{|c|}{ Coal Petrology } & \multirow{2}{*}{$R_{\mathrm{o}} / \%$} \\
\hline & $\mathrm{M}_{\mathrm{ad}} / \%$ & $\mathrm{~A}_{\mathrm{d}} / \%$ & $\mathrm{~S}_{\mathrm{t}} / \%$ & $\mathrm{QMJ} / \mathrm{kg}$ & $\mathrm{V}_{\mathrm{ad}} / \%$ & $\mathrm{FC}_{\mathrm{ad}} / \%$ & Huminite & Liptinite & Inertinite & Inorganic matter & \\
\hline LC-1 & 19.42 & 20.19 & 4.49 & 17.96 & 30.73 & 29.66 & 55.19 & 18.79 & 4.5 & 21.52 & 0.40 \\
\hline LC-2 & 13.3 & 57.33 & 1.26 & 6.94 & 22.02 & 7.34 & - & - & - & & - \\
\hline LC-3 & 13.79 & 52.65 & 1.23 & 9.02 & 18.87 & 14.68 & - & - & - & & - \\
\hline LC-4 & 26 & 38.57 & 1.21 & 12.78 & 15.37 & 20.05 & 69.94 & 11.39 & 1.9 & 16.77 & 0.41 \\
\hline LC-5 & 17.1 & 33.48 & 1.8 & 14.23 & 27.17 & 22.24 & 55.46 & 20.59 & 2.31 & 21.64 & 0.32 \\
\hline LC-6 & 16.6 & 38.33 & 1.07 & 12.49 & 24.71 & 20.35 & 63.24 & 21.89 & 1.35 & 13.52 & 0.40 \\
\hline LC-7 & 12.52 & 56.44 & 0.71 & 6.97 & 19.33 & 11.7 & - & - & - & & - \\
\hline LC-8 & 18.18 & 28.60 & 1.41 & 15.48 & 27.40 & 25.83 & 62.79 & 14.99 & 4.91 & 17.31 & 0.42 \\
\hline LC-9 & 15.6 & 41.78 & 0.97 & 11.44 & 23.14 & 19.48 & - & - & - & & - \\
\hline LC-10 & 10 & 66.04 & 0.28 & 4.19 & 17.54 & 6.42 & - & - & - & & - \\
\hline LC-11 & 10.47 & 65.86 & 0.54 & 4.6 & 15.38 & 8.28 & - & - & - & & - \\
\hline LC-12 & 16.16 & 37.76 & 2.12 & 12.91 & 24.67 & 21.41 & 63.14 & 12.29 & 1.71 & 22.86 & 0.43 \\
\hline LC-13 & 11.52 & 62.96 & 1.02 & 5.45 & 15.63 & 9.9 & - & - & - & & - \\
\hline Average & 15.44 & 46.15 & 1.39 & 10.34 & 21.69 & 16.72 & 61.63 & 16.66 & 2.78 & 18.93 & 0.40 \\
\hline
\end{tabular}

that the Linchang coal is lignite. The maceral composition is dominated by huminite $(55.19 \%$ - 69.94\%, $61.63 \%$ on average), followed by liptinite $(11.39 \%$ $21.89 \%, 16.66 \%$ on average $)$ and little inertinite $(1.90 \%-4.91 \%, 2.78 \%$ on average). The content of inorganic matter in coal is $13.52 \%-22.86 \%$, with an average value of $18.93 \%$.

\subsection{Minerals in Coal Samples}

The composition of minerals in the Linchang coal determined by XRD and Siroquant $^{\mathrm{TM}}$ software is presented (Table 2 \& Figure 2). The coal LTAs mainly consisted of clay minerals such as illite (33.78\%) and kaolinite $(33.31 \%)$, followed by quartz $(19.48 \%)$, as well as a lesser extent, pyrite $(6.04 \%)$, basanite (3.77\%), anhydrite (1.87\%) and siderite (1.18\%). The content of calcite is very tiny $(0.58 \%)$, which may be due to the dissolution of a large amount of calcite under acidic conditions. Yan et al. (2019) found a great deal of eroded calcite in the roof and floor of the Zhoujing mine in Baise basin, and little calcite existed in the coal, further proving that acidic coal-forming environment.

The morphological characteristics of the main minerals in the Linchang coal are shown (Figure 3). Kaolinite is mainly clastic with a stratified structure (Figure $3(\mathrm{a})$ ), which is derived from the detrital materials produced by weathering and denudation of the parent rock in the provenance. Quartz is mostly angular (Figure 3(b)), belonging to a near-source input type (Yan et al., 2019), and often associated with kaolinite. The morphology of pyrite is mainly framboidal (Figure 3(c)) 
Table 2. Mineral content of coal after low-temperature ashing with XRD and Siroquant ${ }^{\mathrm{TM}}$ (\%).

\begin{tabular}{ccccccccc}
\hline Samples & Illite & Kaolinite & Quartz & Pyrite & Bassanite & Anhydrite & Siderite & Calcite \\
\hline LC-1 & & 32.8 & 7.1 & 37.7 & 22.3 & & & \\
LC-2 & 41.2 & 33.2 & 19.3 & 2.0 & & 1.5 & 1.5 & 1.3 \\
LC-3 & 32.8 & 27.7 & 32.0 & 5.1 & & 2.0 & & 0.6 \\
LC-4 & 46.7 & 32.9 & 10.5 & 3.2 & & 1.3 & 3.9 & 1.6 \\
LC-5 & 38.3 & 36.6 & 8.9 & 6.6 & 7.6 & & 2.1 & \\
LC-6 & 43.6 & 35.1 & 15 & 1.6 & & 0.4 & 2.7 & 1.6 \\
LC-7 & 40.5 & 38.1 & 16.8 & 1.3 & & 2.3 & & 1.0 \\
LC-8 & 35.4 & 34.5 & 16.0 & 3.5 & 9.1 & 0.4 & 1.1 & \\
LC-9 & 55.2 & 26.8 & 12.1 & 1.5 & & 0.4 & 3.2 & 0.9 \\
LC-10 & 52.5 & 31.7 & 11.9 & & & 3.3 & & 0.6 \\
LC-11 & 17.6 & 35.6 & 42.7 & 1.3 & & 2.8 & & \\
LC-12 & 35.4 & 26.5 & 19.3 & 7.9 & 10 & & 0.9 & \\
LC-13 & & 41.5 & 41.7 & 6.8 & & 9.9 & & \\
Average & 33.78 & 33.31 & 19.48 & 6.04 & 3.77 & 1.87 & 1.18 & 0.58 \\
\hline
\end{tabular}

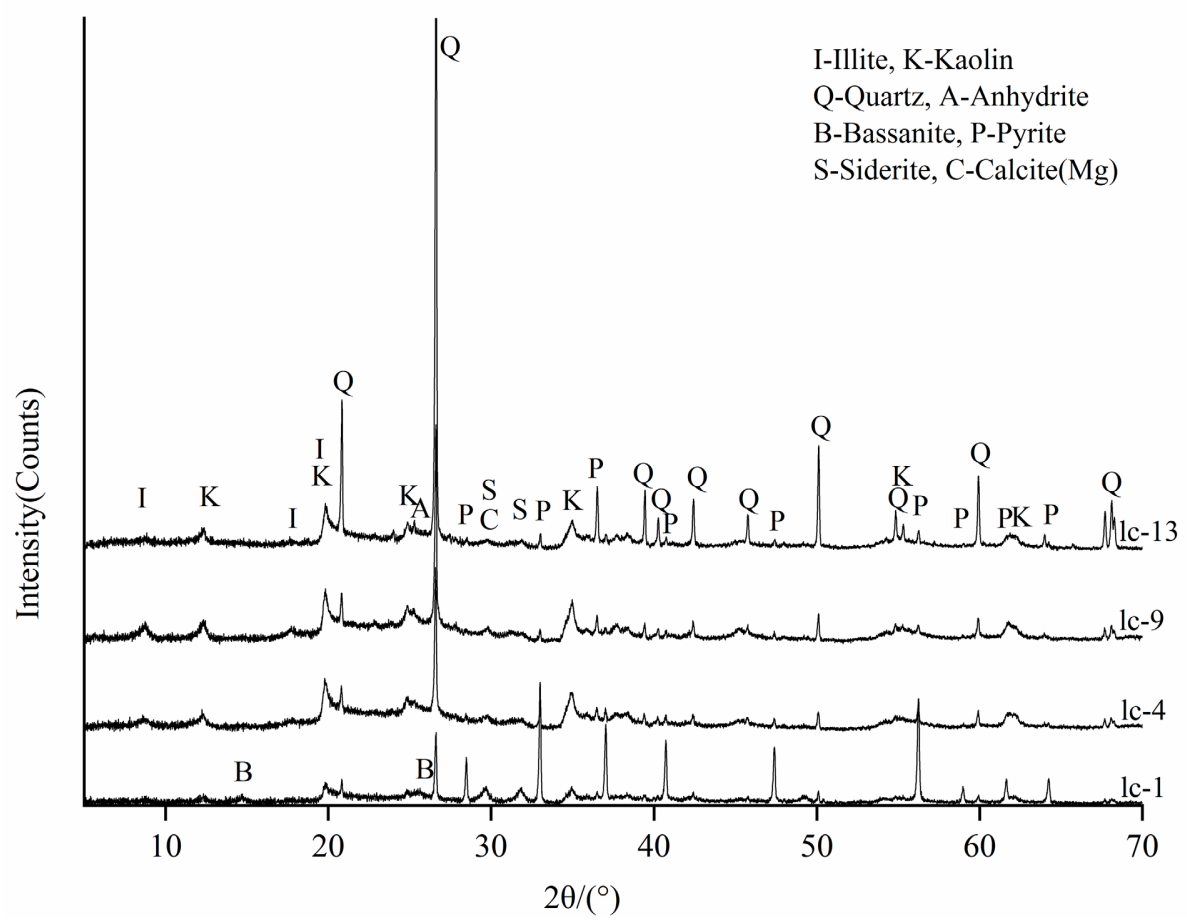

Figure 2. XRD spectra of low-temperature ashing coal from Linchang coal.

and euhedral (Figure 3(d), Figure 3(e)), indicating that pyrite was formed in the peat development stage (Yan et al., 2019). The framboidal pyrite in the coal indicates that the coal-forming environment of Linchang coal is an acidic reducing 


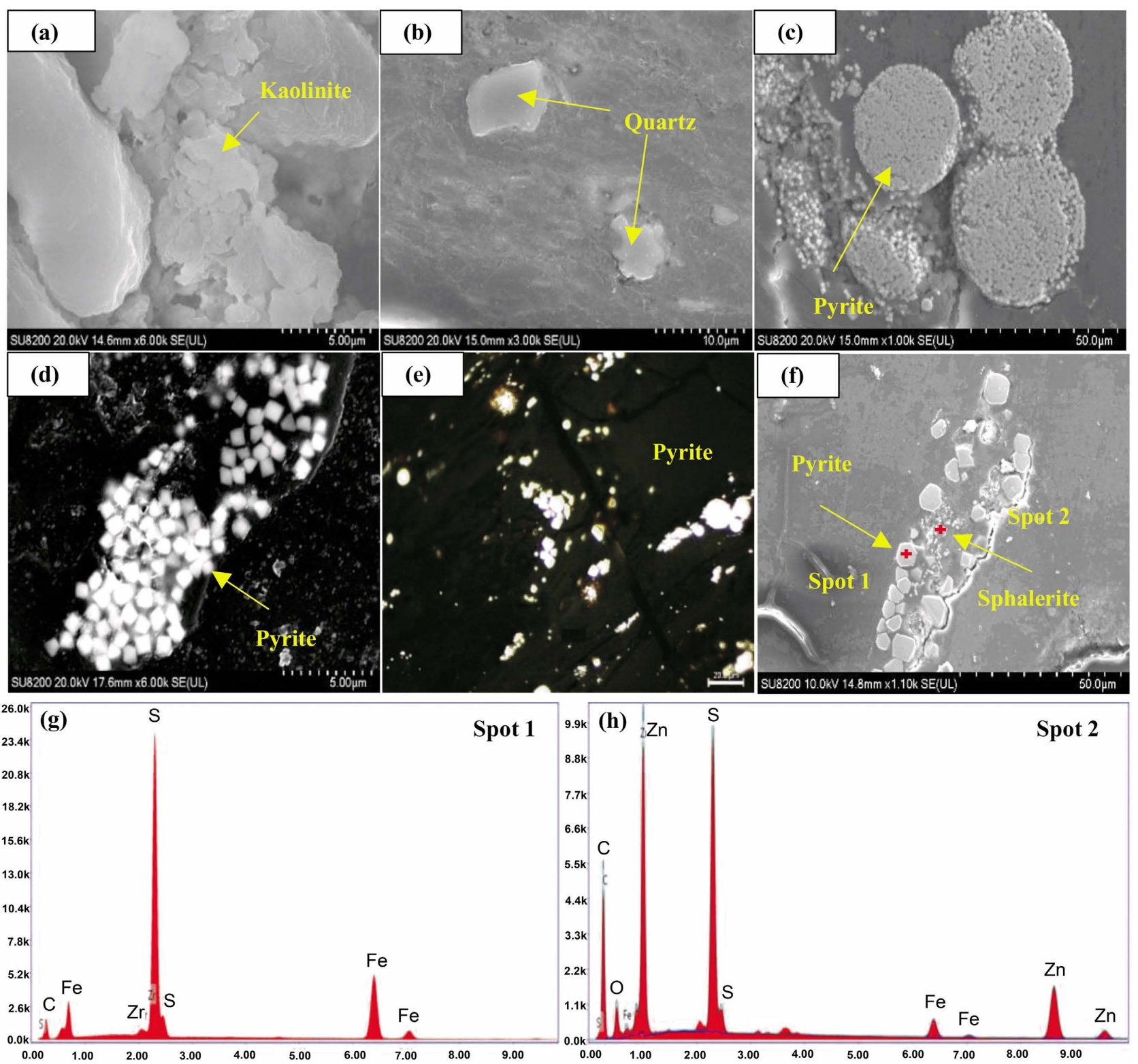

Figure 3. SEM-EDS and polarizing microscope of minerals in Linchang coal, (a) Clastic kaolinite, with bedding structure; (b) Diamond quartz; (c) Framboidal pyrite; (d) and (e) Euhedral pyrite; (f) Sphalerite and euhedral pyrite; (g) Energy spectrum of pyrite; (h) Energy spectrum of sphalerite.

environment, mainly because in an acidic environment, sulfate-reducing bacteria reduce sulfate in the solution to $\mathrm{H}_{2} \mathrm{~S}$, which combines with $\mathrm{Fe}^{2+}$ to generate pyrite (Ward, 2002). There is a close relationship between sphalerite and pyrite (Figure 3(f)). The displacement reaction of $\mathrm{Zn}$ to Fe results in the substitution of pyrite to sphalerite (Figure $3(\mathrm{~h})$ ).

\subsection{Major Element Oxides}

Table 3 lists the content of major element oxides in Linchang coal, mainly $\mathrm{SiO}_{2}$, $\mathrm{Al}_{2} \mathrm{O}_{3}$ and $\mathrm{Fe}_{2} \mathrm{O}_{3}$. The average content of $\mathrm{SiO}_{2}, \mathrm{Al}_{2} \mathrm{O}_{3}$ and $\mathrm{Fe}_{2} \mathrm{O}_{3}$ are 24.64\%, $14.18 \%$ and $2.16 \%$, respectively. The major element content in coal is higher 
D. E. Qi et al.

Table 3. Content of major elements in Linchang coal (\%).

\begin{tabular}{|c|c|c|c|c|c|c|c|c|c|c|c|c|c|}
\hline Samples & $\mathrm{SiO}_{2}$ & $\mathrm{Al}_{2} \mathrm{O}_{3}$ & $\mathrm{Fe}_{2} \mathrm{O}_{3}$ & $\mathrm{CaO}$ & $\mathrm{TiO}_{2}$ & $\mathrm{MgO}$ & $\mathrm{K}_{2} \mathrm{O}$ & $\mathrm{Na}_{2} \mathrm{O}$ & $\mathrm{P}_{2} \mathrm{O}_{5}$ & $\mathrm{MnO}$ & $\mathrm{C}$ & $\mathrm{A} / \mathrm{T}$ & $\mathrm{Si} / \mathrm{Al}$ \\
\hline LC-1 & 6.96 & 4.99 & 3.74 & 1.64 & 0.10 & 0.58 & 0.32 & 0.48 & 0.0309 & 0.0091 & 0.50 & 48.68 & 1.39 \\
\hline LC-2 & 31.20 & 18.39 & 2.49 & 1.04 & 0.46 & 1.08 & 1.39 & 0.54 & 0.0526 & 0.0089 & 0.09 & 40.09 & 1.70 \\
\hline LC-3 & 30.51 & 14.85 & 1.94 & 1.22 & 0.53 & 0.98 & 0.99 & 0.54 & 0.0679 & 0.0097 & 0.09 & 27.93 & 2.05 \\
\hline LC-4 & 19.16 & 12.88 & 1.69 & 1.32 & 0.26 & 0.83 & 1.01 & 0.50 & 0.0257 & 0.0075 & 0.12 & 49.03 & 1.49 \\
\hline LC-5 & 15.58 & 10.73 & 1.98 & 1.53 & 0.22 & 0.76 & 0.85 & 0.50 & 0.0469 & 0.0082 & 0.16 & 49.31 & 1.45 \\
\hline LC-6 & 19.27 & 12.05 & 1.70 & 1.46 & 0.29 & 0.85 & 1.15 & 0.49 & 0.0487 & 0.0076 & 0.13 & 41.36 & 1.60 \\
\hline LC-7 & 30.36 & 18.65 & 1.98 & 1.00 & 0.50 & 1.11 & 1.65 & 0.52 & 0.0587 & 0.0087 & 0.08 & 37.21 & 1.63 \\
\hline LC-8 & 13.70 & 8.49 & 1.40 & 1.60 & 0.26 & 0.70 & 0.57 & 0.48 & 0.0578 & 0.0071 & 0.17 & 32.89 & 1.61 \\
\hline LC-9 & 21.23 & 13.61 & 1.78 & 1.18 & 0.33 & 0.91 & 1.39 & 0.50 & 0.0514 & 0.0074 & 0.11 & 41.24 & 1.56 \\
\hline LC-10 & 34.98 & 23.29 & 2.20 & 0.83 & 0.51 & 1.16 & 1.93 & 0.54 & 0.0713 & 0.0079 & 0.07 & 46.04 & 1.50 \\
\hline LC-11 & 40.64 & 17.99 & 2.04 & 0.90 & 0.70 & 1.21 & 1.23 & 0.54 & 0.1021 & 0.0102 & 0.07 & 25.77 & 2.26 \\
\hline LC-12 & 19.02 & 11.37 & 2.36 & 1.54 & 0.35 & 0.83 & 0.65 & 0.50 & 0.0793 & 0.0085 & 0.16 & 32.12 & 1.67 \\
\hline LC-13 & 37.69 & 17.01 & 2.76 & 1.07 & 0.68 & 1.17 & 1.07 & 0.53 & 0.1253 & 0.0091 & 0.09 & 25.02 & 2.22 \\
\hline Average & 24.64 & 14.18 & 2.16 & 1.26 & 0.40 & 0.94 & 1.09 & 0.51 & 0.06 & 0.0118 & 0.14 & 38.21 & 1.70 \\
\hline Chinese coals & 8.47 & 5.98 & 4.85 & 1.23 & 0.33 & 0.22 & 0.19 & 0.16 & 0.0920 & 0.0150 & & & \\
\hline
\end{tabular}

Notes: Ash composition parameter in coal $\mathrm{C}=\left(\mathrm{Fe}_{2} \mathrm{O}_{3}+\mathrm{CaO}+\mathrm{MgO}\right) /\left(\mathrm{SiO}_{2}+\mathrm{Al}_{2} \mathrm{O}_{3}\right) ; \mathrm{A} / \mathrm{T}=\mathrm{Al}_{2} \mathrm{O}_{3} / \mathrm{TiO}_{2} ; \mathrm{Si} / \mathrm{Al}=\mathrm{SiO} \mathrm{O}_{2} / \mathrm{Al}_{2} \mathrm{O}_{3}$.

than average values in China coal, except for $\mathrm{Fe}_{2} \mathrm{O}_{3}, \mathrm{P}_{2} \mathrm{O}_{5}$ and $\mathrm{MnO}$. The ratio of $\mathrm{SiO}_{2} / \mathrm{Al}_{2} \mathrm{O}_{3}$ is $1.39-2.26$, with an average of 1.70 , which is higher than the mean value of China coal (1.42) and theoretical value of kaolinite (1.18), except LC-1 with $\mathrm{SiO}_{2} / \mathrm{Al}_{2} \mathrm{O}_{3}$ between these two values (1.39). This may be due to the presence of quartz and illite in most coal samples. However, illite was not found in LC-1 (Table 2), so the $\mathrm{SiO}_{2}$ in the LC-1 sample was the only source from kaolinite with a little amount of quartz.

\subsection{Enrichment Characteristics of Valuable Trace Elements in Coal}

Table 4 lists the content, average value and enrichment coefficient (CC) of 14 trace elements in Linchang coal. According to the content level index of trace elements in coal suggested by Dai et al. (2012), the enrichment characteristics are depleted $(\mathrm{CC}<0.5)$, normal $(0.5-2)$, slight enrichment $(2-5)$, enrichment (5 - 10) and high enrichment (10-100), the enrichment characteristics of valuable trace elements in Linchang coal are shown (Figure 4).

The average concentration of $\mathrm{Li}, \mathrm{V}$ and $\mathrm{Ag}$ in coal are $74.60 \mu \mathrm{g} / \mathrm{g}(20.34$ $113.63 \mu \mathrm{g} / \mathrm{g}), 151.54 \mu \mathrm{g} / \mathrm{g}(117.80-197.72 \mu \mathrm{g} / \mathrm{g})$ and $0.53 \mu \mathrm{g} / \mathrm{g}(0.22-0.83 \mu \mathrm{g} / \mathrm{g})$, respectively (Table 4). The content of $\mathrm{Li}, \mathrm{V}$, and $\mathrm{Ag}$ in coal is higher than their average values in the upper crust, Chinese coals and world low-rank coals. For Li in Linchang coal, some of them exceed the suggested industrial cut-off grade of associated lithium in coal $(80 \mu \mathrm{g} / \mathrm{g})$ (Sun et al., 2012). 
Table 4. Content of trace elements in Linchang coal $(\mu \mathrm{g} / \mathrm{g})$.

\begin{tabular}{|c|c|c|c|c|c|c|c|c|c|c|c|c|c|c|c|c|}
\hline Samples & $\mathrm{Li}$ & $\mathrm{Be}$ & $\mathrm{Sc}$ & $\mathrm{V}$ & $\mathrm{Cu}$ & $\mathrm{Zn}$ & $\mathrm{Ga}$ & $\mathrm{Se}$ & $\mathrm{Rb}$ & $\mathrm{Sr}$ & $\mathrm{Ag}$ & Cs & $\mathrm{Ba}$ & $\mathrm{U}$ & $\mathrm{Sr} / \mathrm{Ba}$ & $\mathrm{Cu} / \mathrm{Zn}$ \\
\hline LC-1 & 20.34 & 2.97 & 9.22 & 136.51 & 30.23 & 64.68 & 17.47 & 4.63 & 27.45 & 91.97 & 0.22 & 1.20 & 484.40 & 19.42 & 0.19 & 0.47 \\
\hline LC-2 & 106.24 & 4.98 & 11.09 & 197.72 & 50.45 & 119.65 & 25.42 & 3.66 & 6.61 & 2.82 & 0.67 & 1.08 & 57.43 & 26.38 & 0.05 & 0.42 \\
\hline LC-3 & 80.45 & 2.02 & 11.20 & 150.66 & 39.05 & 86.41 & 18.09 & 3.56 & 7.33 & 4.33 & 0.65 & 1.38 & 71.74 & 31.23 & 0.06 & 0.45 \\
\hline LC- 4 & 63.74 & 2.07 & 9.42 & 150.35 & 39.58 & 89.93 & 20.27 & 3.47 & 7.13 & 4.12 & 0.46 & 2.16 & 107.34 & 18.24 & 0.04 & 0.44 \\
\hline LC-5 & 53.35 & 1.88 & 8.52 & 135.50 & 33.42 & 77.18 & 17.63 & 5.30 & 14.31 & 8.32 & 0.35 & 2.43 & 180.93 & 28.85 & 0.05 & 0.43 \\
\hline LC-6 & 46.39 & 1.74 & 7.51 & 117.80 & 30.00 & 62.78 & 19.41 & 3.06 & 13.26 & 4.98 & 0.35 & 4.27 & 140.00 & 10.35 & 0.04 & 0.48 \\
\hline LC-7 & 102.31 & 2.50 & 9.17 & 149.64 & 42.47 & 109.84 & 25.10 & 2.07 & 9.34 & 2.46 & 0.58 & 1.27 & 48.21 & 11.53 & 0.05 & 0.39 \\
\hline LC-8 & 55.39 & 1.87 & 7.39 & 127.13 & 38.05 & 74.44 & 17.08 & 3.83 & 21.59 & 28.99 & 0.33 & 3.00 & 280.95 & 56.57 & 0.10 & 0.51 \\
\hline LC-9 & 50.49 & 2.32 & 8.35 & 142.69 & 31.03 & 68.63 & 21.29 & 2.82 & 9.95 & 3.21 & 0.41 & 2.40 & 81.57 & 34.40 & 0.04 & 0.45 \\
\hline LC-10 & 113.63 & 2.69 & 11.89 & 170.52 & 35.98 & 110.31 & 30.04 & 1.04 & 15.76 & 2.68 & 0.70 & 4.78 & 37.41 & 22.71 & 0.07 & 0.33 \\
\hline LC-11 & 101.67 & 2.29 & 12.34 & 160.67 & 27.24 & 131.76 & 25.80 & 1.67 & 5.82 & 2.90 & 0.82 & 1.84 & 60.91 & 45.54 & 0.05 & 0.21 \\
\hline LC-12 & 80.67 & 2.66 & 11.39 & 149.15 & 41.61 & 83.02 & 19.63 & 6.33 & 11.59 & 10.34 & 0.56 & 2.48 & 200.95 & 70.25 & 0.05 & 0.50 \\
\hline LC-13 & 95.14 & 3.83 & 13.63 & 181.71 & 53.16 & 103.61 & 21.31 & 3.10 & 6.10 & 3.76 & 0.83 & 1.97 & 76.40 & 27.64 & 0.05 & 0.51 \\
\hline Average & 74.60 & 2.60 & 10.09 & 151.54 & 37.87 & 90.94 & 21.43 & 3.43 & 12.02 & 13.14 & 0.53 & 2.33 & 140.63 & 31.01 & 0.09 & 0.42 \\
\hline Min & 20.34 & 1.74 & 7.39 & 117.80 & 27.24 & 62.78 & 17.08 & 1.04 & 5.82 & 2.46 & 0.22 & 1.08 & 37.41 & 10.35 & 0.07 & 0.43 \\
\hline Max & 113.63 & 4.98 & 13.63 & 197.72 & 53.16 & 131.76 & 30.04 & 6.33 & 27.45 & 91.97 & 0.83 & 4.78 & 484.40 & 70.25 & 0.19 & 0.40 \\
\hline The upper crust & 20.00 & 3.00 & 13.60 & 107.00 & 25.00 & 71.00 & 17.00 & 0.08 & 112.00 & 350.00 & 0.05 & 4.60 & 550.00 & 2.80 & & \\
\hline Chinese coals & 31.80 & 2.11 & 4.38 & 35.10 & 17.50 & 41.40 & 6.55 & 2.47 & 9.25 & 140.00 & nd & 1.13 & 159.00 & 2.43 & & \\
\hline World coals & 10.00 & 1.20 & 4.10 & 22.00 & 15.00 & 18.00 & 5.50 & 1.00 & 10.00 & 120.00 & 0.09 & 0.98 & 150.00 & 2.90 & & \\
\hline $\mathrm{CC}$ & 7.46 & 2.17 & 2.46 & 6.89 & 2.52 & 5.05 & 3.90 & 3.43 & 1.20 & 0.11 & 5.92 & 2.38 & 0.94 & 10.69 & & \\
\hline
\end{tabular}

Notes: Data about Chinese coals are from (Dai et al., 2012); the upper crust data are from (Taylor \& Mclennan, 1985); world coals data are from (Ketris \& Yudovich, 2009); CC = the content of trace elements in Linchang coal/world coals.

The content of Be is $1.74-4.98 \mu \mathrm{g} / \mathrm{g}$, with an average value of $2.60 \mu \mathrm{g} / \mathrm{g}$, which is higher than the Chinese coals and the world low-rank coals, but lower than the upper crust (Table 4), showing slight enrichment (Figure 4). The Be content in Permian coal in South China is $0.6-3 \mu \mathrm{g} / \mathrm{g}$ with an average of 2 $\mu \mathrm{g} / \mathrm{g}$ (Zhao et al., 2002), and its content in Linchang coal is mostly higher than this value.

The average content of $\mathrm{Ga}$ and Se in coal is $21.43 \mu \mathrm{g} / \mathrm{g}(17.08-30.04 \mu \mathrm{g} / \mathrm{g})$ and $3.43 \mu \mathrm{g} / \mathrm{g}(1.04-6.33 \mu \mathrm{g} / \mathrm{g})$, respectively (Table 4). Both of them are higher than the upper crust value, the Chinese coals and the world low-rank coals, showing slight enrichment (Figure 4). The concentration of $\mathrm{Ga}$ in coal and coal gangue is generally $0-20 \mu \mathrm{g} / \mathrm{g}$ in Baise basin (Zhang et al., 2019), and the average value of $\mathrm{Ga}$ in Linchang coal is higher than this value. Although the content of $\mathrm{Ga}$ in Linchang coal does not exceed the industrial utilization grade 


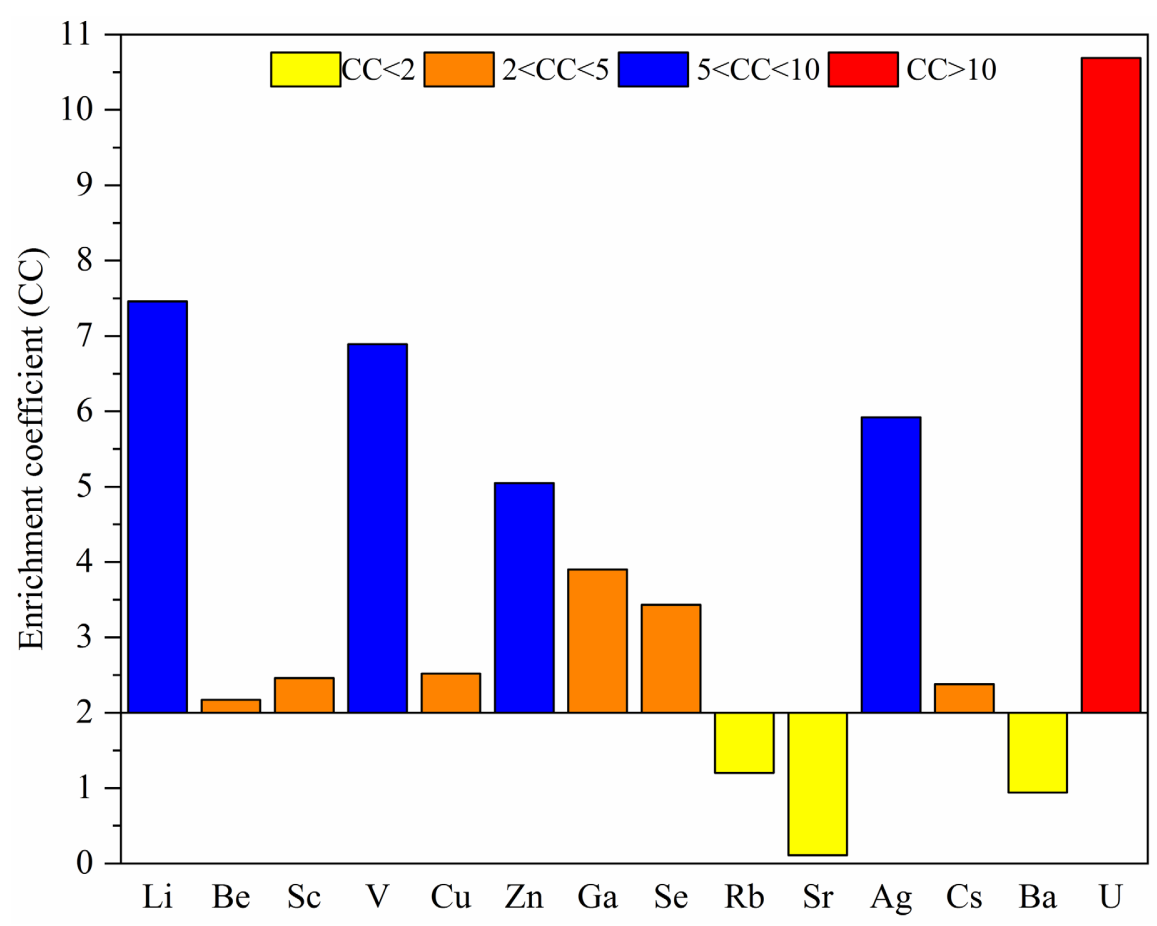

Figure 4. Enrichment coefficient of trace elements in Linchang coal.

(30 $\mu \mathrm{g} / \mathrm{g})$ (Ren \& Dai, 2009), considering that the Ga content is not low, especially Ga will be further enriched in coal ash, which may reach the value of exploitation and utilization. Therefore, it is necessary to conduct an in-depth survey of the Ga content in this area. The Se content in Linchang coal is higher than that of Chinese lignite $(2.22 \mu \mathrm{g} / \mathrm{g})$ and Paleogene coal $(1.57 \mu \mathrm{g} / \mathrm{g})$ (Zhang et al., 2007).

The content of $U$ is $10.35-70.25 \mu \mathrm{g} / \mathrm{g}$, with an average value of $31.01 \mu \mathrm{g} / \mathrm{g}$, which is higher than the Chinese coals, the world low-rank coals and the upper crust value (Table 4). Compared to world coals, the above trace elements are characterized by high enrichment (Figure 4). $\mathrm{U}$ is generally enriched in Guangxi coal, and its content can reach up to several hundred ppm (Lauer et al., 2017). Compared with coals of other geological ages, the content of $U$ in Paleogene and Neogene coal is significantly higher (Chen et al., 2017), and the result of this study is consistent with previous studies. Sun et al. (2014) proposed that the comprehensive recycling value of coal associated $\mathrm{U}$ element is $40 \mu \mathrm{g} / \mathrm{g}$, and the content of U in samples LC-8, LC-11 and LC-12 are $56.57 \mu \mathrm{g} / \mathrm{g}, 45.54 \mu \mathrm{g} / \mathrm{g}$ and $70.25 \mu \mathrm{g} / \mathrm{g}$, respectively, which all exceed the threshold value.

\subsection{Occurrence of Valuable Trace Elements in Coal}

SPSS software was used to analyze the correlation between trace elements and major elements, ash and total sulfur content in Linchang coal at the $95 \%$ confidence level ( $n=13$, the critical value of correlation coefficient $r$ is 0.553$)$, and the correlation coefficients are shown in Table 5. According to the correlation analysis, combined with the results of XRD, SEM-EDS and polarizing microscope, the occurrence of valuable trace elements in coal is inferred. 
The correlation coefficient of $\mathrm{Li}, \mathrm{V}, \mathrm{Ga}$, and Ag is 0.647 - 0.903, showing moderate or high positive correlation with each other, and their correlation coefficient with ash content is $0.737-0.939$, indicating that these elements may have similar inorganic mineral sources and occurrence modes. The $\mathrm{Li}$ in coal is mainly related to clay minerals (kaolinite and chlorite), boehmite and other inorganic components, partly combined with organic matter (Qin et al., 2015b). Recent leaching experiments have shown that about $90 \%$ of $\mathrm{Li}$ in most high-rank coals is related to aluminosilicates (clay and mica), while about $50 \%$ of low-rank coals is related to organic matter (Finkelman et al., 2017). Although Linchang coal is low-rank coal, $\mathrm{Li}$ is highly correlated with ash yield (0.917), $\mathrm{Al}_{2} \mathrm{O}_{3}(0.914)$ and $\mathrm{SiO}_{2}$ (0.891), indicating that Li mainly occurs in clay minerals, which is due to the high ash content of Linchang coal. Clay mineral usually has a negative charge and interlayer structure, and is easy to undergo cation exchange with metal ions (Finkelman et al., 2019), which is conducive to the adsorption of Li. Therefore, the occurrence mode of $\mathrm{Li}$ is adsorbed on the surface of clay minerals such as illite and kaolinite in Linchang coal. $\mathrm{V}$ in coal may be related to clay, and exist organically in low-rank coals (Finkelman et al., 2017). In this case, V has a moderate correlation with ash yield (0.737) and $\mathrm{Al}_{2} \mathrm{O}_{3}$ (0.695) in Linchang coal, illustrating that most of $\mathrm{V}$ are present in clay minerals, and partly in combination with organic matter. It may be that the organically bound $\mathrm{V}$ was released during coalification and subsequently absorbed by clay minerals (Finkelman et al., 2017). There are three occurrence modes of Ga in coal: inorganic, organic and mixed. The primary inorganic carrier is clay mineral (Qin et al., 2015a). This is because $\mathrm{Ga}$ and $\mathrm{Al}$ have similar chemical properties, and $\mathrm{Ga}$ can replace $\mathrm{Al}$ in aluminous phases by isomorphism (Dai et al., 2008). Ren et al. (2006) have shown that $\mathrm{Ga}$ in coal results form isomorphism in clay minerals. $\mathrm{Ga}$ is positively correlated with ash yield (0.813) and $\mathrm{Al}_{2} \mathrm{O}_{3}$ (0.900) in Linchang coal, and it may enter kaolinite and illite in the form of isomorphism. Qin et al. (2018) found that Ag in Zhongliangshan coal in Chongqing is mainly related to sulfide, followed by silicate. In Linchang coal, Ag is correlated highly with ash yield (0.939), $\mathrm{Al}_{2} \mathrm{O}_{3}(0.823)$ and $\mathrm{SiO}_{2}(0.960)$, but is not correlated or negatively correlated with $\mathrm{Fe}_{2} \mathrm{O}_{3}(0.018)$ and total sulfur (-0.614), indicating that its main carrier may be kaolinite or illite.

The occurrence mode of Be in coal is complex, which may be combined with organic matter and clay minerals. When the content of Be is high, the organic affinity is dominant, and when the content is low, it is mainly present in clay minerals (Eskenazy, 2006; Finkelman et al., 2017). Be has a low correlation with ash yield (0.379), $\mathrm{Al}_{2} \mathrm{O}_{3}(0.338)$ and $\mathrm{SiO}_{2}$ (0.356) in Linchang coal, indicating that carriers of Be are inorganic minerals, together with organic matter. Although Be occurs in organic components in low-rank coals rich in humic acid, the ash content in Linchang coal is relatively high, and the organically bound Be turns to be bound with clay minerals during the coalification process (Finkelman et al., 2017). This is due to that $\mathrm{Be}$ and $\mathrm{Al}$ are both amphoteric elements, and they 
Table 5. Correlation analysis of trace elements in Linchang coal.

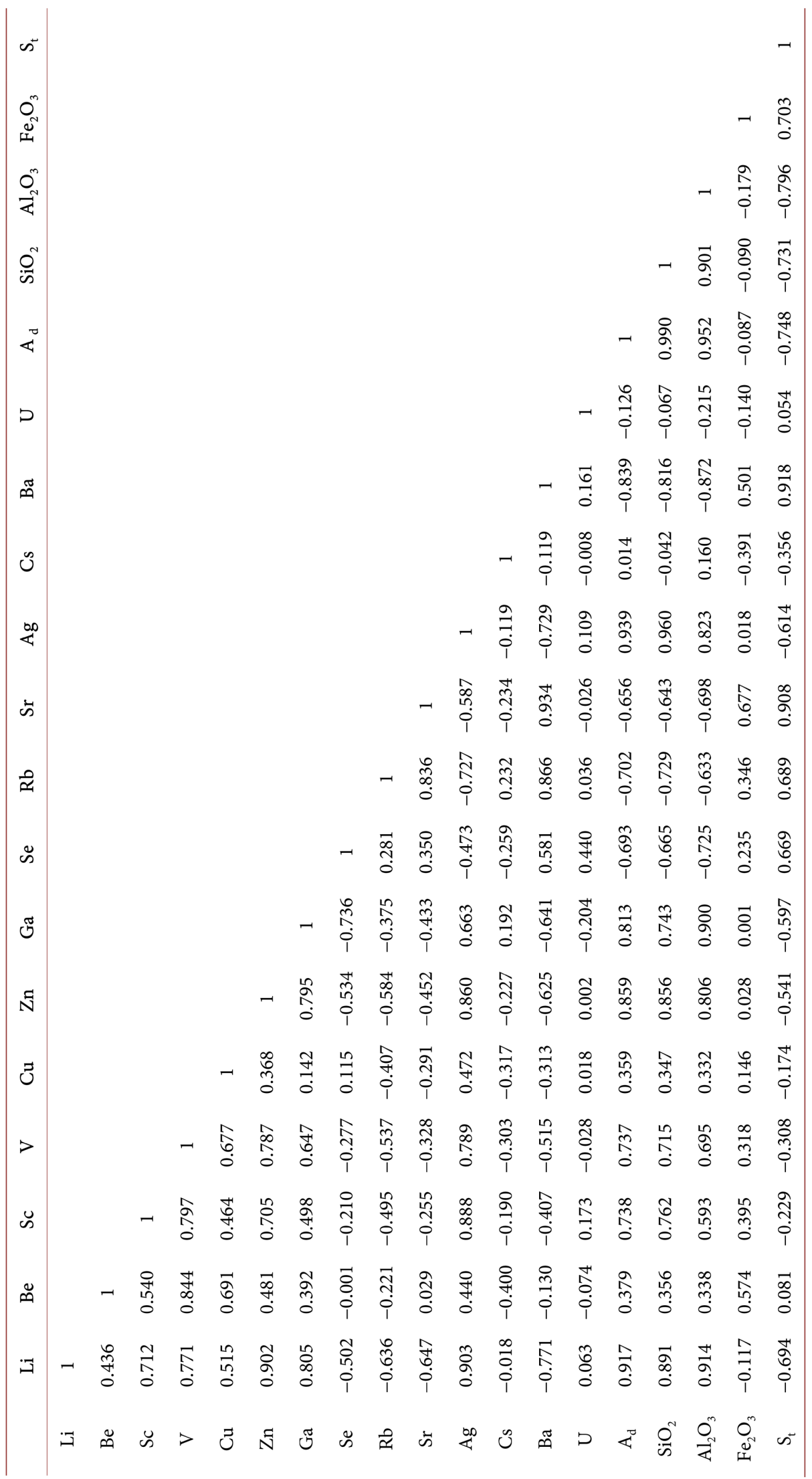


can also replace $\mathrm{Al}$ in the crystal lattice of Al-containing clay minerals or be adsorbed by them.

Previous studies have shown that organic binding is the main form of Se in coal, followed by sulfide and selenide (Li \& Ren, 2006). Most of the Se in low-rank coal is organically combined, and only a small part is related to sulfide and silicate (Finkelman et al., 2017). During the coalification process, the organically connected Se is gradually transformed into the sulfide form (Wang, 2012). Selenium has a moderately negative correlation with ash yield $(-0.693)$, and a moderate correlation with total sulfur (0.669) in Linchang coal, indicating that the main carriers of Se may be pyrite and organic matter. In medium and high sulfur coal, Se mainly occurs in pyrite, while in low sulfur coal, the mode of occurrence is related to organic matter (Zhang et al., 2007). Although Linchang coal belongs to medium and high sulfur coal, its maturity is very low, and Se is basically unrelated to $\mathrm{Fe}_{2} \mathrm{O}_{3}$ (0.235). Therefore, Se is mainly combined with organic matter, and its occurrence form may be organic sulfur, with a small amount that exists in pyrite.

The main carriers of $U$ in Chinese coal are organic matter and silicate (Chen et al., 2017). However, $\mathrm{U}$ in coal is always strongly associated organically, especially in low-rank coal, where is a large amount of humic acid. In humic acid, $\mathrm{UO}_{2}^{2+}$ has an exchange reaction with $\mathrm{H}^{+}$, thereby combining with the organic matter in coal (Qin et al., 2018). U in Yimin lignite mainly occurs in an organically bound form or an organic adsorbed state (Yang et al., 2011). There is almost no correlation between $U$ and ash yield $(-0.126)$ in Linchang coal, indicating that it mainly occurs in organic matter. Linchang coal is low-rank coal and contains abundant humus, which favors the adsorption and complexation of $\mathrm{U}$ by organic matter.

\subsection{Enrichment Origin of Valuable Trace Elements in Coal}

The enrichment of trace elements in coal may be controlled by many factors such as the source rock, low-temperature hydrothermal fluid, volcanic ash, magmatic fluid, sedimentary environment, groundwater and submarine jets (Dai et al., 2012). Some elements are more sensitive to environmental changes, and are often used as geochemical indicators, which have significance for the study of coal-forming environment and sediment sources.

According to available investigation, the enrichment of most trace elements in coal (such as $\mathrm{Li}, \mathrm{Ga}$, etc.) is mainly derived from terrestrial sedimentary sources (Qin et al., 2015a; Qin et al., 2015b). However, the initial source of Se may be the Se protein (bacteria, algae, or higher plants) in the precursor material of coal (Riley et al., 2007). The ratio of $\mathrm{Al}_{2} \mathrm{O}_{3} / \mathrm{TiO}_{2}$ can indicate the sediment source of coal seam: $\mathrm{Al}_{2} \mathrm{O}_{3} / \mathrm{TiO}_{2}$ is between $8-21$, which means that the sediments are derived from neutral rocks, and $21-70$ are from felsic rocks (Yan et al., 2019). The value of $\mathrm{Al}_{2} \mathrm{O}_{3} / \mathrm{TiO}_{2}$ in Linchang coal ranges from 25.02 to 49.31 (38.21 on average), indicating that the inorganic matter in Linchang coal comes from felsic rocks (Table 3). The source of $U$ in most coals is $U$-rich felsic igneous rocks 
(Chen et al., 2018). It can be seen that the Triassic sedimentary rocks derived from the felsic igneous rocks around the Baise basin provide a source for the enrichment of valuable trace elements in Linchang coal (Yan et al., 2019). In general, the lithologic association of mudstone, sandstone and coal may provide a place for the redox, migration and deposition of $U$ (Chen et al., 2018), so this is another enrichment factor of $U$ in Linchang coal.

$\mathrm{SiO}_{2}$ and $\mathrm{Al}_{2} \mathrm{O}_{3}$ usually come from terrestrial input during peat accumulation, while the content of $\mathrm{Fe}_{2} \mathrm{O}_{3}, \mathrm{CaO}$ and $\mathrm{MgO}$ can reflect the degree of transgression. The ash composition parameter $\mathrm{C}$ in coal can be used as a classification index of terrestrial facies $(\mathrm{C}<0.23)$ and peat swamps affected by seawater $(\mathrm{C}>$ 0.23) (Ye et al., 1997). The value of $\mathrm{Sr} / \mathrm{Ba}$ greater than 1 indicates marine environment, and conversely, terrestrial deposit (Wei et al., 2018; Wang et al., 2021). The ash parameter $\mathrm{C}$ in Linchang coal ranges from 0.07 to 0.50 ( 0.14 on average) (Table 3); Sr/Ba ratio ranges from 0.04 to 0.19 (0.06 on average) (Table 4), both indicating that the coal seams are mainly terrestrial peat swamp deposition. However, the ash composition parameter C of LC- 1 is 0.50 , illustrating that this area is affected by seawater, which is obviously contrary to the basin's sedimentary environment. It may be affected by the acidic underground circulating water around the basin, leading to the increase of solute concentration and producing more pyrite in LC-1, which makes this parameter larger (Yan et al., 2019). In the sediment, $\mathrm{Cu} / \mathrm{Zn}<0.21$ reflects the reducing environment, and $\mathrm{Cu} / \mathrm{Zn}>0.63$ reflects the oxidizing environment. $0.21<\mathrm{Cu} / \mathrm{Zn}<0.63$ represents the weak oxidation-weak reduction environment (Liu, 2018). The $\mathrm{Cu} / \mathrm{Zn}$ range of Linchang coal is $0.21-0.51$ ( 0.43 on average), indicating that the coal forming environment of Linchang coal is weak oxidation-reduction deposition. Kaolinite is easily formed and preserved in a medium acidic environment, and framboidal pyrite indicates an acidic reducing environment (Ward, 2002). The mineral composition of Linchang coal conforms that the coal formed under an acidic reducing environment (Figure $3(\mathrm{c})$ ).

In addition, investigations have shown that regional geological tectonic activities impact the provenance and sedimentary environment of the coal-forming basin. For example, the uplift of the Luliang Peninsula has made the lithium-rich bauxite deposits of the Benxi group in the Ningwu basin as a direct source of lithium in coal (Sun et al., 2013). Faults often provide pathways and locations for the enrichment of $U$ in coal. The Baise basin is located in the middle of the Youjiang fold belt of the South China fold system. It is a half graben basin with a complex geological structure and relatively developed faults, which is also one of the causes for the enrichment of valuable trace elements in Linchang coal. It can be concluded that the enrichment of valuable trace elements in Linchang coal is jointly influenced by sediment sources, coal-forming environment, underground circulating water, and geological tectonic.

\section{Conclusion}

The maceral of Linchang coal is dominated by huminite, and the huminite ref- 
lectance $\left(R_{\mathrm{o}}\right)$ is $0.40 \%$. It is ultra-low calorific value lignite with high ash, medium sulfur, medium-high moisture, and medium volatile content. The mineral composition is mainly clay minerals including illite and kaolinite, followed by quartz, and to a lesser extent, pyrite, basanite, anhydrite, siderite and calcite.

The enrichment characteristics of valuable trace elements in Linchang coal are as follows: $\mathrm{U}$ is highly enriched; $\mathrm{Li}, \mathrm{V}$ and $\mathrm{Ag}$ are enriched; $\mathrm{Be}, \mathrm{Ga}$ and Se are lightly enriched. The elements $\mathrm{Li}, \mathrm{V}, \mathrm{Ga}$ and $\mathrm{Ag}$ in Linchang coal are all moderately or highly correlated with each other, indicating that these elements may have a similar inorganic mineral source and occurrence mode. The elements $\mathrm{Li}$, $\mathrm{V}, \mathrm{Ga}$ and Ag mainly occur in clay minerals such as illite and kaolinite, among which part of $\mathrm{V}$ is related to organic matter. The carriers of Be are inorganic minerals and organic matter. Se is mainly combined with organic matter, and its occurrence may be organic sulfur, with a small amount occurring in pyrite. $U$ primarily exists in coal in an organically bound form. The ash composition parameters $\mathrm{C}, \mathrm{Al}_{2} \mathrm{O}_{3} / \mathrm{TiO}_{2}, \mathrm{Sr} / \mathrm{Ba}, \mathrm{Cu} / \mathrm{Zn}$, and mineral composition all reflect that coal seam is acidic reduction terrestrial peat swamp deposition, and the sediment source is Triassic sedimentary rocks weathered from felsic volcanic rocks around Baise basin. The enrichment of valuable trace elements in Linchang coal is affected by sediment source, coal-forming environment, underground circulating water and geological tectonic. This work supplies a fundamental knowledge for potential application to enhance metal recycling from coal or combustion residuals.

\section{Acknowledgments}

Special thanks are given to editors and reviewers for their careful reviews. We gratefully acknowledge financial support from the National Natural Science Foundation of China (42172191), the Science Foundation of Hebei (D2021402013, D2019402181), and Key Science and Technology Foundation in Universities of Hebei Province (ZD2019055).

\section{Conflicts of Interest}

The authors declare no conflicts of interest regarding the publication of this paper.

\section{References}

Chen, J., Chen, P., Yao, D. X., Huang, W. H., Tang, S. H., Wang, K. J., Liu, W. Z. et al. (2018). Geochemistry of Uranium in Chinese Coals and the Emission Inventory of Coal-Fired Power Plants in China. International Geology Review, 60, 621-637. https://doi.org/10.1080/00206814.2017.1295284

Chen, J., Chen, P., Yao, D. X., Huang, W. H., Tang, S. H., Wang, K. J., Liu, W. Z. et al. (2017). Abundance, Distribution, and Modes of Occurrence of Uranium in Chinese Coals. Minerals, 7, Article No. 239. https://doi.org/10.3390/min7120239

Dai, S. F., Li, D., Chou, C. L., Zhao, L., Zhang, Y., Ren, D. Y., Ma, Y. W. et al. (2008). Mineralogy and Geochemistry of Boehmite-Rich Coals: New Insights from the Haerwusu 
Surface Mine, Jungar Coalfield, Inner Mongolia, China. International Journal of Coal Geology, 74, 185-202. https://doi.org/10.1016/j.coal.2008.01.001

Dai, S. F., Ren, D. Y., Chou, C. L., Finkelman, R. B., Seredin, V. V., \& Zhou, Y. P. (2012). Geochemistry of Trace Elements in Chinese Coals: A Review of Abundances, Genetic Types, Impacts on Human Health, and Industrial Utilization. International Journal of Coal Geology, 94, 3-21. https://doi.org/10.1016/j.coal.2011.02.003

Dai, S. F., Yan, X. Y., Ward, C. R., Hower, J. C., Zhao, L., Wang, X. B., Zhao, L. X. et al. (2018). Valuable Elements in Chinese Coals: A Review. International Geology Review, 60, 590-620. https://doi.org/10.1080/00206814.2016.1197802

Eskenazy, G. M. (2006). Geochemistry of Beryllium in Bulgarian Coals. International Journal of Coal Geology, 66, 305-315. https://doi.org/10.1016/j.coal.2005.07.005

Finkelman, R. B., Dai, S.F., \& French, D. (2019). The Importance of Minerals in Coal as the Hosts of Chemical Elements: A Review. International Journal of Coal Geology, 212, Article ID: 103251. https://doi.org/10.1016/j.coal.2019.103251

Finkelman, R. B., Palmer, C. A., \& Wang, P. P. (2017). Quantification of the Modes of Occurrence of 42 Elements in Coal. International Journal of Coal Geology, 185, 138-160. https://doi.org/10.1016/j.coal.2017.09.005

Ketris, M. P., \& Yudovich, Y. E. (2009). Estimations of Clarkes for Carbonaceous Biolithes: World Averages for Trace Element Contents in Black Shales and Coals. International Journal of Coal Geology, 78, 135-148.

https://doi.org/10.1016/j.coal.2009.01.002

Lauer, N., Vengosh, A., \& Dai, S. F. (2017). Naturally Occurring Radioactive Materials in Uranium-Rich Coals and Associated Coal Combustion Residues from China. Environmental Science \& Technology, 51, 13487-13493. https://doi.org/10.1021/acs.est.7b03473

Li, S. S., \& Ren, D. Y. (2006). Analysis of Anomalous High Concentration of Lead and Selenium and Their Origin in the Main Minable Coal Seam in the Junger Coalfield. Journal of China University of Mining \& Technology, 35, 612-616.

Liao, Z. T., Jiang, X. G., Li, R., \& Chen, Y. K. (2005). Research on the Tectono-thermal Evolution of the Baise Basin, Guangxi Province. Petroleum Geology \& Experiment, 27, 18-24.

Liu, R. (2018). Application of Trace Elements in Coal Analysis of Coal-forming Environment. Anhui University of Science \& Technology.

Ning, S. Z., Deng, X. L., Li, C. C., Qin, G. H., Zhang, J. Q., Zhu, S. F., Qiao, J. W. et al. (2017a). Research Status and Prospect of Metal Element Mineral Resources in China. Journal of China Coal Society, 42, 2214-2225.

Ning, S. Z., Huang, S. Q., Zhu, S. F., Zhang, W., Deng, X. L., Li, C. C., Qiao, J. W., et al. (2017b). Mineralization Zoning of Coal-Metal Deposits in China. Chinese Science Bulletin, 64, 2501-2513. https://doi.org/10.1360/N972019-00377

Qin, S. J., Lu, Q. F., Gao, K., Bo, P. H., \& Wu, S. H. (2018). Geochemistry of Elements Associated with Late Permian Coal in the Zhongliangshan Mine, Chongqing, Southwest China. Energy Exploration \& Exploitation, 36, 1655-1673. https://doi.org/10.1177/0144598718768980

Qin, S. J., Lu, Q. F., Li, Y. H., Wang, J. X., Zhao, Q. J., \& Gao, K. (2018). Relationships between Trace Elements and Organic Matter in Coals. Journal of Geochemical Exploration, 188, 101-110. https://doi.org/10.1016/j.gexplo.2018.01.015

Qin, S. J., Sun, Y. Z., Li, Y. H., Wang, J. X., Zhao, C. L., \& Gao, K. (2015a). Coal Deposits as Promising Alternative Sources for Gallium. Earth-Science Reviews, 150, 95-101. https://doi.org/10.1016/j.earscirev.2015.07.010 
Qin, S. J., Zhao, C. L., Li, Y. H., \& Zhang, Y. (2015b). Review of Coal as a Promising Source of Lithium. International Journal of Oil, Gas and Coal Technology, 9, 215-229. https://doi.org/10.1504/IJOGCT.2015.067490

Ren, D. Y., \& Dai, S. F. (2009). Potential Coexisting and Associated Mineral Resources in Coal and Coal-bearing Strata-An Issue Should Pay Close Attention to. Coal Geology of China, 21, 1-4.

Ren, D. Y., Zhao, F. H., \& Dai, S. F. (2006). Trace Element Geochemistry of Coal. Science Press.

Riley, K. W., French, D. H., Lambropoulos, N. A., Farrell, O. P., Wood, R. A., \& Huggins, F. E. (2007). Origin and Occurrence of Selenium in Some Australian Coals. International Journal of Coal Geology, 72, 72-80. https://doi.org/10.1016/j.coal.2006.12.010

Seredin, V. V., \& Dai, S. F. (2012). Coal Deposits as Potential Alternative Sources for Lanthanides and Yttrium. International Journal of Coal Geology, 94, 67-93. https://doi.org/10.1016/j.coal.2011.11.001

Sun, S. L., Wu, G. Q., Cao, D. Y., Ning, S. Z., Qiao, J. W., Zhu, H. X., Han, L., et al. (2014). Mineral Resources in Coal Measures and Development Trend. Coal Geology of China, 26, 1-11.

Sun, Y. Z., Yang, J. J., \& Zhao, C. L. (2012). Minimum Mining Grade of Associated Li Deposits in Coal Seams. Energy Exploration \& Exploitation, 30, 167-170. https://doi.org/10.1260/0144-5987.30.2.167

Sun, Y. Z., Zhao, C. L., Li, Y. H., \& Wang, J. X. (2014). Minimum Mining Grade of the Selected Trace Elements in Chinese Coal. Journal of China Coal Society, 39, 744-748.

Sun, Y. Z., Zhao, C. L., Zhang, J. Y., Yang, J. J, \& Zhang, Y. Z. (2013). Concentrations of Valuable Elements of the Coals from the Pingshuo Mining District, Ningwu Coalfield, Northern China. Energy Exploration \& Exploitation, 31, 727-744. https://doi.org/10.1260/0144-5987.31.5.727

Taylor, S. R., \& Mclennan, S. M. (1985). The Continental Crust: Its Composition and Evolution. Blackwell.

Wang, A. H., Wang, Z. H., Liu, J.K., Xu, N. C., \& Li, H. L. (2021). The Sr/Ba Ratio Response to Salinity in Clastic Sediments of the Yangtze River Delta. Chemical Geology, 559, Article ID: 119923. https://doi.org/10.1016/j.chemgeo.2020.119923

Wang, L. (2012). Selenium in Chinese Coal: Distribution, Mode of Occurrence and Environmental Geochemistry. University of Science and Technology of China.

Wang, T. G., \& Simoneit, B. R. T. (1990). Organic Geochemistry and Coal Petrology of Tertiary Brown Coal in the Zhoujing Mine, Baise Basin, South China: 2. Biomarker Assemblage and Significance. Fuel, 69, 12-20. https://doi.org/10.1016/0016-236190252-L

Ward, C. R. (2002). Analysis and Significance of Mineral Matter in Coal Seams. International Journal of Coal Geology, 50, 135-168. https://doi.org/10.1016/S0166-516200117-9

Wei, W., Algeo, T. J., Lu, Y., Lu, Y. C., Liu, H., Zhang, S., Peng, L. et al. (2018). Identifying Marine Incursions into the Paleogene Bohai Bay Basin lake System in Northeastern China. International Journal of Coal Geology, 200, 1-17. https://doi.org/10.1016/j.coal.2018.10.001

Yan, X. Y., Dai, S. F., Graham, I. T., French, D., \& Hower, J. C. (2019). Mineralogy and Geochemistry of the Palaeogene Low-rank Coal from the Baise Coalfield, Guangxi Province, China. International Journal of Coal Geology, 214, Article ID: 103282. https://doi.org/10.1016/j.coal.2019.103282 
Yang, J. Y., Di, Y. Q., Zhang, W. G., \& Liu, S. D. (2011). Geochemistry Study of its Uranium and Other Element of Brown Coal of ZK0161 Well in Yili Basin. Journal of China Coal Society, 36, 945-952.

Ye, D. M., Luo, J. W., \& Xiao, W. Z. (1997). Origin and Application of Coal Macerals in Southwest China. Geological Publishing House.

Zhang, F. Q., Liao, J. L., Zhao, G. H., \& Zhou, L, J. (2019). Coal Measures Associated and Accompanying Mineral Resources Features and Exploitation Status in Guangxi. Coal Geology of China, 31, 1-5, 11.

Zhang, Y., Liu, G. J., Deng, L. G., Chou, C. L., \& Qi, C. C. (2007). Environmental Geochemistry of Selenium in Chinese Coal. Bulletin of Mineralogy, Petrology and Geochemistry, 26, 389-398.

Zhao, J. Y., Tang, X. Y., \& Huang, W. H. (2002). Abundance of Trace Elements in Coal of China. Coal Geology of China, 14, 6-14, 18.

Zhao, S. Q., Zhong, N. N., Xiong, B., Simoneit, B. R. T., \& Wang, T. G. (1990). Organic Geochemistry and Coal Petrology of Tertiary Brown Coal in the Zhoujing Mine, Baise Basin, South China: 1. Occurrence and Significance of Exudatinite. Fuel, 69, 4-11.

https://doi.org/10.1016/0016-236190251-K 